DOI 10.18551/rjoas.2019-02.12

\title{
ANALYSIS OF RUBBER FARMER WELFARE IN JAMBI PROVINCE, INDONESIA
}

\author{
Kuswanto \\ Department of Economic Education, University of Jambi, Indonesia \\ *E-mail: kuswanto.fkip@unja.ac.id
}

\begin{abstract}
Most of the people of Jambi Province work in the rubber plantation sector. The welfare of farmers is largely determined by rubber productivity and price levels. This study aims to analyze the level of income and expenditure ratios as a measure of the level of welfare of rubber farmer households. Data obtained by conducting a survey of 120 farmers in the central area of rubber plantations in Jambi Province. The welfare of farmers is analyzed using the Farmer Household Income Exchange (NTPRP) approach. The results of the analysis show that the average rubber farmer in Jambi Province is not as prosperous as indicated by NTPRP of $0.97<1$. Rubber farmers allocate more income to consumption needs compared to the needs of rubber farming. From the results of this study, it is expected that farmers make priority scale fulfillment of needs and do not neglect the financing of rubber farming and add other businesses, such as livestock and fisheries.
\end{abstract}

\section{KEY WORDS}

Welfare, rubber, farmers, public service.

Jambi Province is one of the largest rubber producing regions in Indonesia. Based on data from DIRJENBUN (2017), there are 214,168 farmers or around 24.48 percent of the total households in Jambi Province working in the rubber plantation sector. Apart from being the main source of income for the community, rubber plantations are also the largest source of foreign exchange for Jambi Province. Thus, the existence of the development of rubber plantations greatly determines the economy of the community in particular and the regional economy in general.

The support of plantation estates on the community's economy is determined by the level of productivity and the competitiveness of products produced both in the local and international markets. This support has implications for the level of income obtained by farmers from the plantation sector developed. Income is the main capital for farmers to carry on business and family life. In various studies, such as BPS, BKKBN, and Sugiarto (2008), making income a benchmark for farmers' purchasing power towards family needs. The fulfilment of family needs for food, clothing, housing, and family needs that can be measured materially from income reflects family welfare (Sunarti, 2006). Systemically, well-being can be seen as an output/result of the use of available inputs (resources), where welfare as an output at a point and becomes an input to produce the level of family welfare in the next stage. In the long term, the level of welfare will further strengthen the position of farmers in developing rubber farming.

Measuring the welfare of farmers is needed as a correction of the sustainability of rubber plantations developed. Welfare measurements are carried out subjectively and objectively at the level of individuals, families and society. Subjectively, indicators of individual well-being are feelings of happiness or feelings of sadness, peace or mental anxiety, and satisfaction or dissatisfaction. Indicators of family welfare can be seen in family satisfaction with housing conditions. Objectively, indicators of family welfare can be seen in the adequacy of housing conditions (compared to standards), such as the availability of clean water, lighting, and so on. At the community level, welfare is based on infant mortality, unemployment and homelessness (Cambell in Sunarti, 2006).

Sajogyo (1997) measures welfare using the concept of minimum needs (calories) based on the conversion of rice consumed by the family. BKKBN measures family welfare by using 23 derivative indicators, while BPS measures welfare through minimum needs so that 
the amount changes according to inflation rates or changes in prices of basic needs. The results of measurements of family welfare were conducted by Rambe, et all. (2008) using the BKKBN criteria, BPS, Food Expenditure, and Subjective Perception. The BKKBN criteria, BPS and Food Expenditure have an accuracy of $63 \%$ in identifying prosperous families while Subjective Perception is $22 \%$.

The measurement of farmer family welfare was carried out by Sugiarto (2008) using the concept of Farmer Household Income Exchange (NTPRP), which is a measure of the ability of farmer households to meet their subsistence needs or also called Subsistence Term of Trade. The NTPRP method is a development of the NTP method used by BPS in measuring the level of welfare of farmers. In the BPS concept, which is formulated as a Subsistent Exchange Rate (NTS) is the exchange rate of all agricultural businesses, but it has not included farm hunting and non-agricultural sectors that are large enough to contribute to the household income of farmers (Rahmat et al., 2000). Therefore according to Rachmat et al., 2000; Basuki et al. (2001), Simatupang \& Maulana (2007), which the concept of "Rural Household Income Exchange Value (NTPRP)" is the ratio between total household income and total household expenditure.

The welfare marker of farmers using NTP is the only approach for observers of agricultural development (Simatupang \& Maulana, 2007). The approach used by Sugiarto (2008) in explaining the welfare of farmers using the concept of Farmer Household Income Exchange (NTPRP), which is a measure of the ability of households to meet their subsistence needs. The higher the exchange rate of farmers will further reflect the welfare of farmer households.

Based on the explanation above, it is necessary to study the level of welfare of farmers by analyzing the level of income generated from rubber farming and the level of household expenditure so as to produce information that is useful for making policies to strengthen rubber cultivation as a support for the community economy and regional economy.

\section{METHODS OF RESEARCH}

The method used in this study is quantitative in the form of a survey. Data and information about income and expenditure of farmer households are obtained by using questionnaires. The population in this study were farmers as owners and cultivators of rubber plantations and made the farming as the main source of income for the family. Because rubber plantations in Jambi Province are very extensive, sampling area techniques are used to determine the number of samples to be examined, namely by determining several districts from the sample area from the district, sub-district and village levels. Respondents were randomly selected from each village with 120 farmers.

The family welfare of rubber farmers is analyzed using the concept of Farmer Household Income Value (NTPRP), which is the ratio between total household income and total household expenditure. The total income of agricultural households is the sum of income from rubber farming, other farming income and income from non-agricultural businesses. While the total expenditure of farmer households is the sum of expenses for farming or production costs (production costs of rubber farming, other farming costs and production costs of non-agricultural businesses) and expenditures for family consumption (food and non-food).

The income of rubber farmers comes from rubber farming and other farming and nonagricultural businesses. Mathematically the income is formulated in equation (1).

$$
Y=Y_{p k}+Y_{p l}+Y_{n p}
$$

Where: $Y$ - farmer's income; $Y_{p k}$ - rubber farming income; $Y_{p l}$ - Other farming income; $Y_{n p}$ non-agricultural income.

Based on data from the National Farmers Panel (PATANAS) in 2005, the source of income of farmer household agriculture in addition to plantations is rice farming / farming, 
livestock farming and farm labor. While non-agricultural businesses consist of trading businesses, industrial businesses, service businesses, transportation businesses and nonagricultural workers as well as civil servants / TNI. In this study, farmers who were sampled were farmers whose income was mostly (> $80 \%$ ) originating from keretani farming. This is intended so that the effect of the efficiency of rubber production has a portion that is relevant in forming NTPRP.

Expenditures of rubber farmers constitute overall expenditure in farmer households. According to BPS (2015), the expenditure of farmer households consists of production costs (seeds, fertilizers, land rent, taxes, transportation) and additional capital and household consumption (food, processed food, housing, clothing, health, education, recreation, sports, transportation and communication In accordance with the objectives of the research to be carried out, the expenditure of farmers is classified as expenditures for rubber farming, agricultural expenditure other than rubber, non-agricultural expenditure and expenditure for consumption of household consumption can be formulated mathematically as in equation (2):

$$
E=E_{p k}+E_{p l}+E_{n p}
$$

Where: E - farmer expenditure; Epk - rubber farming expenditure; Epl - farming expenditure other than rubber; Enp - expenditure on non-agricultural business.

By comparing the total income received by farmers with the total household expenditure, NTPRP will be generated as a measure of the level of welfare of farmers, as in the following equation (3).

$$
\begin{array}{r}
N T P R P=\frac{Y}{E} \\
N T P R P=\frac{Y_{p k}+Y_{p l}+Y_{n p}}{E_{p k}+E_{p l}+E_{n p}}
\end{array}
$$

If NTPRP $>1$ shows that farm households have prospered. However, if NTPRP $<1$, shows that farm households are not yet prosperous. That is, if NTPRP $>1$ shows that in order to meet household welfare levels, farmers are relatively more allocated to meet consumption needs than business needs.

\section{RESULTS AND DISCUSSION}

The use of NTPRP as an approach to measuring household welfare of farmers requires information or data on farmers' income and household expenditure, where NTPRP is the ratio between income and household expenditure of farmers. Farmer income is obtained from rubber farming run by farmers for one year. Household farmer expenditure consists of expenditure on rubber farming costs, food consumption expenditure and non-food expenditure.

The respondents chosen in this study were rubber farmers who made rubber farming the main source of income for the family. Thus farmers' income is obtained from the sale of production at a certain price level. As explained in Table 1, the following:

Table 1 - Rubber Farmer Income

\begin{tabular}{lllll}
\hline No & Income Elements & Average & Maximum & Minimum \\
\hline 1 & Production $(\mathrm{kg})$ & 3,876 & 18,000 & 1,200 \\
2 & Price (Rp) & 7,403 & 9,000 & 6,500 \\
3 & Income (Rp) & $25,247,100$ & $81,600,000$ & $8,400,000$ \\
\hline
\end{tabular}

Source: Primary data, 2017 (processed). 
In Table 1, the average production produced by farmers for one year is $3,876 \mathrm{Kg}$ and the average price received by farmers is Rp.7,403. On the level of production and price, the average income obtained by farmers from rubber farming for one year is Rp.25,247,100, while the highest income received by farmers is Rp.81,600,000 and the lowest income received by farmers is Rp.8,400,000. When compared with the level of per capita income in Jambi Province, there are only 4 percent of rubber farmers in the research area whose income is above the per capita income (Rp.54,366,369)

Household expenditure on rubber farmers consists of expenditures for rubber farming financing and expenditure for household consumption, as shown in Table 2, the following:

Table 2 - Household Expenditures for Rubber Farmers

\begin{tabular}{lllll}
\hline No & Expenditures & Average & Max & Min \\
\hline 1 & Production cost & $1,116,033$ & $21,710,000$ & 261,000 \\
2 & Food material & $14,053,250$ & $34,392,000$ & $6,630,000$ \\
3 & Not Food & $7,891,500$ & $29,160,000$ & $2,100,000$ \\
4 & Energy & $3,038,600$ & $7,680,000$ & $1,476,000$ \\
\hline & total & $26,099,383$ & $92,942,000$ & $10,467,000$ \\
\hline
\end{tabular}

Source: Primary data, 2017 (processed).

Expenditures for household consumption consist of food consumption and non-food consumption and energy expenditure. In Table 2, the average household expenditure of rubber farmers in the one year period in the study area is Rp.26,099,383, the highest expenditure of Rp.92,942,000 and the lowest expenditure is Rp.10,467,000. From the expenditure, expenditures for foodstuffs have a higher portion compared to other expenditures, namely an average of Rp.14,053,250, while the lowest portion is used for financing rubber farming, which is an average of Rp.1,116,033 and other expenditures for non-food items amounting to Rp.7,971,500 and expenditure for energy amounting to Rp.3,038,600.

Household expenditure on rubber farmers in financing rubber farming is determined by the level of use of inputs at a certain price level. The use of inputs that directly cause production costs is the use of fertilizers, herbicides and production equipment. The preference of farmers who consider the use of inputs as very important in rubber production and supported by the ability of income to finance inputs will increasingly determine the amount of production costs. There are several inputs that are produced from within the farmer's family, namely labour. So that its use does not directly lead to production costs, as explained in Table 3, the following:

Table 3 - Rubber Farming Financing Expenditures

\begin{tabular}{llll}
\hline Production cost & Average & Maximum & Minimum \\
\hline Fertilizer & 497,167 & $17,250,000$ & 125,000 \\
Herbicide & 227,500 & $1,400,000$ & 65,000 \\
Equipment & 391,367 & $3,060,000$ & 71,000 \\
\hline total & $1,116,033$ & $21,710,000$ & 261,000 \\
\hline
\end{tabular}

Source: Primary data, 2017 (processed).

In Table 3, the average production cost in the study area for one year was Rp.1,116,033. The maximum production cost is $R p .21,710,000$ and the minimum cost is Rp.261,000. From such funding, the financing for the procurement of fertilizers has the largest portion compared to the procurement of other inputs, which is an average of Rp.497,167 and the lowest portion for financing herbicide use is Rp.27,500.

Household expenditure on rubber farmers for consumption consists of food consumption, non-food consumption and energy sources. The largest portion of household rubber household consumption expenditure in the study area was used for food consumption, which was an average of one year in the amount of Rp.14,053,250, while the 
lowest portion was used for energy expenditure in the amount of $R p \cdot 3,038,600$ and Rp.7,971,500.

Household expenditure on rubber farmers for food consumption consists of energy sources, food ingredients, nuts, vegetables and fruits, vegetable oil, spices, tobacco and other consumption. The average household expenditure of rubber farmers for food consumption in the study area for one year was Rp.14,053,350. The highest household expenditure for food consumption is Rp.34,392,000 and the lowest is Rp.6,630,000. Of these expenditures, the largest portion (27\%) was used for animal food consumption consisting of meat and fish of Rp.2,798,800 and eggs and milk of Rp.862,800. Another expenditure that also has a large share of food consumption expenditure is expenditure on carbohydrates, which consists of rice consumption of Rp.3,337,300 and non-rice for Rp.16,900.

Table 4 - Rubber Farmers Household Food Consumption Expenditures, 2017

\begin{tabular}{llll}
\hline FOOD CONSUMPTION TYPES & Average & Maximum & Minimum \\
\hline A. Source of Carbohydrates & & & $1,800,000$ \\
1. Rice & $3,337,300$ & $6,000,000$ & 0 \\
2. Non Rice & 16,900 & 600,000 & \\
B. Animal Food & & & $1,260,000$ \\
1. Meat + Fish & $2,798,800$ & $6,600,000$ & 90,000 \\
2. Eggs + Milk & 862,800 & $2,136,000$ & 0 \\
3. Others & 125,000 & $2,400,000$ & 60,000 \\
C. Nuts & & & 240,000 \\
Tahu + Tempe + Others & 716,450 & $2,160,000$ & 144,000 \\
D. Vegetables and Fruits & $1,590,200$ & $5,040,000$ & 168,000 \\
E. Oil and fat & 610,150 & $1,680,000$ & 240,000 \\
F. Beverage Materials (White Sugar + Tea + Coffee) & 913,050 & $2,928,000$ & 0 \\
G. Spices & $1,250,800$ & $3,600,000$ & 0 \\
H. Tobacco & $1,509,900$ & $14,400,000$ & 0 \\
I. Other consumption & 321,900 & $4,800,000$ & 0 \\
\hline TOTAL & $14,053,250$ & $34,392,000$ & $6,630,000$ \\
\hline
\end{tabular}

Source: Primary data, 2017 (processed).

In Table 4, expenditures on vegetables and fruits have a sizeable portion in food consumption expenditures, which is 11.32 percent or Rp.1,590,200. Other consumption expenditures that have a large portion are tobacco consumption expenditures, reaching 10.74 percent or Rp.1,509,900.

Non-food consumption expenditures of rubber farmer households consist of expenditures for health care, consumption, communication and transport which are issued for one year. Expenditures for health care in the household of rubber farmers, including the cost of medical treatment and the purchase of food / beverage health supplements. Expenditures for education are carried out as funding for education for members who attend PUD to tertiary education. In general, rubber farm households have communication equipment in the form of mobile phones. Its use is a source of household expenditure for communication. Expenditures for transportation are carried out by rubber farm households as an effort to finance transportation needs related to rubber farming and others. In detail, household expenditure on rubber farmers for non-food consumption is shown in Table 5 , as follows:

Table 5 - Household Expenditures for Rubber Farmers for Non-Food Consumption

\begin{tabular}{llll}
\hline NOT FOOD MATERIALS & AVERAGE & MAXIMUM & MINIMUM \\
\hline 1. Health Care & $1,451,600$ & $3,600,000$ & 480,000 \\
2. Education & $2,358,000$ & $22,080,000$ & 0 \\
3. Communication & $1,078,300$ & $2,700,000$ & 240,000 \\
4. Transportation & $3,003,600$ & $9,600,000$ & 768,000 \\
\hline TOTAL & $7,891,500$ & $29,160,000$ & $2,100,000$ \\
\hline
\end{tabular}

Source: Primary data, 2017 (processed). 
In Table 5, the average household expenditure of rubber farmers for non-food consumption is Rp.7,891,500. The highest expenditure is Rp.29,160,000 and the lowest expenditure is Rp. $2,100,000$. The biggest portion of non-food expenditure is for transportation expenditures, which is Rp.3,003,600 and education expenses are Rp.2,358,000, while other expenses such as health care amount to Rp.1,451,600 and expenditures for communication amounting to Rp.1,078,300.

The high expenditure of farmer households for transportation is characterized by the level of mobility of farmers and family members in carrying out day-to-day activities. Mobilization of farmers which raises transportation costs related to their efforts in managing rubber plantations and other family businesses. Family member affiliation which also contributes to family expenses related to transportation fulfilment of learning needs.

Expenditures of farmer families for education are indirect education for family members, such as the cost of school uniforms, shoes, bags, books, pens and other equipment. While direct education funding (SPP) in general has been borne by the government. Especially for family members who are in higher education, education expenses include direct and indirect costs. Thus, the high family expenses for education are determined by the large number of family members attending school at the tertiary level.

The use of fuel or energy in the household of rubber farmers in general is to fulfil lighting needs, turn on electronic equipment and cooking needs. The average household size of rubber farmers in the study area uses electricity and gas to support family life activities. The ease of access to electricity and gas by farmer households has reduced the use of kerosene as an energy source for farmer households, as shown in Table 6, the following:

Table 6 - Household Expenditures of Rubber Farmers for Fuel / Energy

\begin{tabular}{llll}
\hline Type of Fuel & Average & Maximum & Minimum \\
\hline Kerosene & 94,600 & 960,000 & 0 \\
Electricity & $2,162,300$ & $5,400,000$ & 900,000 \\
Solar & 23,700 & $2,700,000$ & 0 \\
LPG & 758,000 & $3,480,000$ & 264,000 \\
\hline TOTAL & $3,038,600$ & $7,680,000$ & $1,476,000$ \\
\hline
\end{tabular}

Source: Primary data, 2017 (processed).

In Table 6, the average annual household expenditure of rubber farmers for fuel / energy is Rp.3,038,600, the maximum expenditure of Rp.7,680,000 and a minimum of Rp.1,476,000. From the various fuels used by the rubber farmer households, electricity is the biggest energy source utilized by the farmer family to support family activities. The average farm household expenditure for electricity sources for one year is Rp.2,162,300, the highest expenditure is Rp.5,400,000 and the lowest expenditure is Rp.900,000. This condition shows that access to electricity as a family energy ingredient has reached most of the respondents' agricultural areas.

The family expenditure for the next energy material which is of considerable value is the use of gas / LPG, which is an average of one year of Rp.758,000, the highest is Rp.3,480,000 and the lowest is Rp.264,000. The high expenditure of farmer families for energy gas materials indicates that most families of rubber farmers in the study area have converted the use of kerosene and firewood as energy materials to gas energy sources. While the use of diesel fuel as an energy material is only carried out by some rubber farming families for the benefit of alternative energy fuels, such as Diesel.

The level of welfare of rubber farmer families is measured using the Farmer Household Income Exchange (NTPRP) approach. Where NTPRP is the ratio between income and household expenditure of rubber farmers. Households of rubber farmers are considered prosperous if NTPRP $>1$. However, if NTPRP $<1$, then the rubber farmer household is not considered prosperous. The results of the analysis of farmers' welfare are explained in Table 7, as follows: 
Table 7 - Exchange of Farmer Household Income (NTPRP) Rubber

\begin{tabular}{ll}
\hline DESCRIPTION & AVERAGE / FARMERS (Rp.) \\
\hline A. INCOME & $25,247,100$ \\
B. PRODUCTION COSTS & $1,116,033$ \\
C. CONSUMPTION & $24,983,350$ \\
1. Food Consumption & $14,053,250$ \\
2. Non-Food Consumption & $7,891,500$ \\
3. Fuel consumption & $3,038,600$ \\
D. TOTAL EXPENDITURE & $26,099,383$ \\
E. VALUE OF EXCHANGE INCOME & \\
1. Against Total Expenditures & 0.97 \\
2. Against Production Costs & 22.62 \\
3. Against Food Consumption & 1.80 \\
4. Against Non-Food Consumption & 3.20 \\
5. Against Fuel Consumption & 8.31 \\
6. Against Total Consumption & 1.01 \\
\hline
\end{tabular}

Source: Primary data, 2017 (processed).

From the results of the analysis in Table 7, the NTPRP average of total expenditure is smaller than one, which is 0.97 . This explains that the average rubber farmer household is not yet prosperous. This condition occurs because the amount of expenditure for both food and non-food consumption has a greater effect on the amount of income compared to other NTPRP formation components. The amount of NTPRP to total consumption (1.01) is smaller than NTPRP to total production costs (22.62). This condition explains that to achieve the level of household welfare, rubber farmers allocate more income for consumption needs compared to the needs of rubber farming.

If viewed from the level of household consumption of rubber farmers, NTPRP on food consumption (1.80) is smaller than NTPRP on non-food consumption (3.20), as well as NTPRP on fuel (8.31). This condition explains that the achievement of farmer household welfare is done by allocating more income for food consumption needs compared to nonfood and fuel consumption needs.

Based on the results of the study, it was explained that the issue of farmers' welfare was not only determined by rubber production and the level of consumption of farmer households. The factor that cannot be controlled by farmers to achieve family welfare is rubber prices and prices of goods for household consumption needs. In Thailand, the welfare of rubber farmers is largely determined by the price level that develops in the rubber market. If the price of rubber increases, the welfare of farmers will increase and vice versa if the price of rubber falls, the welfare of farmers will decrease (Yamaka, at all. 2017).

\section{CONCLUSION}

Based on the results and discussion above, it can be concluded that the average rubber farmer in Jambi Province has not been prosperous as indicated by NTPRP of $0.97<1$. To achieve the level of household welfare, rubber farmers allocate more income to consumption needs compared to farming needs rubber. Achieving household welfare of farmers is done by allocating more income for food consumption needs compared to nonfood and fuel consumption needs.

\section{SUGGESTIONS}

The low allocation of income towards farming finance has an impact on the low production of rubber. Costs are a consequence of farming run by farmers. Therefore, farmers must make a priority scale on financing household consumption so that their income can be allocated to rubber farming which is more beneficial. Besides that, other businesses are needed to support the family economy, such as livestock, fisheries and other farming. 


\section{REFERENCES}

1. [DIRJENBUN]. Direktorat Jenderal Perkebunan (2017). Statistik Perkebunan Indonesia. Dirjenbun. Jakarta. Retrieved from: http://ditjenbun.pertanian.go.id/tinymcpuk/ gambar/file/statistik/2017/Karet-2015-2017.pdf

2. Basuki, R., Hadi, P., U., Panaji, T., Ilham, N., Sugiarto, Hendiarto, Winarso, B., Hartoyo, D., Setiawan, I. 2001. Pedoman Teknis Nilai Tukar Nelayan. Dirjen Pesisir dan Pulaupulau Kecil. Departemen Kelautan dan Perikanan. Jakarta, Indonesia

3. Rachmat, M., Supriyati, D., Hidayat dan Situmorang, J. 2000. Perumusan Kebijaksanaan Nilai Tukar Petani dan Komoditas Pangan Pertanian. Laporan Hasil Penelitian. Badan Pusat Penelitian Sosial Ekonomi Pertanian. Departemen Pertanian. Bogor.

4. Rambe, A., Hartoyo \& Karsin, E., S. 2008. Analisis Alokasi Pengeluaran dan Tingkat Kesejahteraan Keluarga (Studi di Kecamatan Medan Kota, Sumatera Utara). Jurnal Ilmu Keluarga \& Konsumen 1:16-28

5. Sajogyo, T. 1997. Garis Kemiskinan dan Kebutuhan Minimum Pangan. LPSB-IPB. Bogor, Indonesia. Retrieved from: https://repository.ipb.ac.id/handle/123456789/24089

6. Simatupang, P. \& Maulana, M. (2007). Kaji Ulang Konsep Nilai Tukar Petani Tahun 2003-2006 [Review the concepts and developments of farmer exchange rates in 20032006]. Journal of Economics and Development. LIPI. Jakarta, Indonesia. Retrieved from: http://pse.litbang. pertanian.go.id/ind/pdffiles/ Anjak_2007_IV_05.pdf

7. Sugiarto. 2008. Analisis tingkat kesejahteraan petani menurut pola pendapatan dan pengeluaran di pedesaan. Pusat Analisis Sosial Ekonomi dan Kebijakan Pertanian. Badan Litbang Pertanian. Bogor, Indonesia. 248-260. Retrieved from: http://pse.litbang.pertanian. go.id/ind/pdffiles/MS_B6.pdf

8. Sunarti, E. 2006. Indikator kesejahteraan keluarga: sejarah perkembangan, evaluasi dan keberlanjutan. IPB. Bogor, Indonesia. Retrieved from: http://dp2m.umm.ac.id/files/file/DrEuis-Sunarti-Indikator-Keluarga-Sejahtera.pdf

9. Yamaka, W., Sriboonchitta, S., Phochanachan, P., \& Pastpipatkul P. 2017. Welfare Measurement on Thai Rubber Market. International Journal of Applied Business and Economic Research. 15 (7): 209-221. 